\title{
Review Study on Sciencedirect Library Based on Coronavirus Covid-19
}

\author{
Muzhir Shaban Al-Ani', Dimah Mezher Shaban Al-Ani² \\ ${ }^{1}$ Department of Information Technology, College of Science and Technology, University of Human Development, \\ Sulaymaniyah, Iraq, ${ }^{2}$ Department of Pharmacy, College of Pharmacy, University of Philadelphia, Amman, Jordan
}

\section{A B S T R A C T}

Several years ago, China and the United States of America began experimenting with the coronavirus, which lives in the bat. It is not known until now how the virus spread and how it extended to all countries of the world. However, it is certain that this virus first appeared and spread was at the end of 2019 and in the Chinese city of Wuhan, especially in markets close to laboratories that are working on this virus. At the beginning of the year 2020, this virus began to spread very widely all over the world and began killing thousands of people every day. The world economy was destroyed until the World Health Organization considered it a pandemic. As for the research aspect, the researchers started the research work on this pandemic from many aspects, including medical, statistical, managerial, healthcare, and others. A statistical analysis depends many key factors that have been studied. This study was conducted on April 11, 2020, where a large number of research papers were downloaded using the keywords coronavirus disease (COVID)-19, which were applied in the Sciencedirect library that was examined on 100 research papers only. The obtained results indicated that most of the research papers that worked on the subject of COVID-19 confirmed that this virus infects the human respiratory system, which in turn leads to shortness of breath and death. Here, it must be noted that the human immune system has a major role in the process of overcoming this virus and gradual recovery. The obtained analysis indicated that the main fields of coronavirus are: Medicine $42 \%$, statistics $21 \%$, healthcare $19 \%$, and management $18 \%$. Through this study, it became clear that China is the first country in terms of the number of researchers and also in terms of the number of research papers related to the COVID-19.

Index Terms: Coronavirus, Coronavirus Disease-19, Diagnosis, Human Immune System, Coronavirus Disease-19 Published Papers.

\section{INTRODUCTION}

Coronaviruses are a large group of viruses that may cause disease in animals and humans. It is known that a number of coronaviruses cause human respiratory infections that range from common colds to more severe diseases such as the Middle East Respiratory Syndrome and severe

\begin{tabular}{|l|l|}
\hline \multicolumn{2}{|c|}{ Access this article online } \\
$\begin{array}{l}\text { DOI:10.21928/uhdjst.v4n2y2020.pp46-55 } \\
\text { E-ISSN: 2521-4217 } \\
\text { P-ISSN: 2521-4209 }\end{array}$ \\
\hline $\begin{array}{l}\text { Copyright @ 2020 Al-Ani and Al-Ani. This is an open access article } \\
\text { distributed under the Creative Commons Attribution Non-Commercial } \\
\text { No Derivatives License 4.0 (CC BY-NC-ND 4.0) }\end{array}$ \\
\hline
\end{tabular}

acute respiratory syndrome (SARS). The newly discovered coronavirus causes the Covid-19 virus. Coronavirus disease (COVID)-19 is an infectious disease caused by the newly discovered coronavirus. There was no knowledge of this virus and this emerging disease before the outbreak of outbreak in the Chinese city of Johan in December 2019. The most common symptoms of COVID-19 disease are fever, fatigue, and dry cough. Some patients may experience pain and aches, nasal congestion, cold, sore throat, or diarrhea. These symptoms are usually mild and begin gradually. Some people become infected without showing any symptoms and without feeling ill. Moreover, the severity of the disease intensifies in approximately one person out of every six people who develop COVID-19 infection, who suffer from

Corresponding author's e-mail: Muzhir Shaban Al-Ani, Department of Information Technology, College of Science and Technology, University of Human Development, Sulaymaniyah, Iraq. E-mail: Muzhir.al-ani@uhd.edu.iq

Received: 26-06-2020 Accepted: 28-07-2020 Published: 06-08-2020 
difficulty breathing. The risk of the elderly and people with basic medical problems such as high blood pressure, heart disease, or diabetes is severe. About $2 \%$ of people who have contracted the disease have died. People with fever, cough, and difficulty breathing should seek medical care. The term "incubation period" refers to the period from infection with the virus to the onset of symptoms of the disease. Most estimates of the incubation period for COVID-19 disease range from 1 to 14 days, usually lasting 5 days. These estimates will be updated as more data becomes available.

A section of Kingston University's Microbiologists has concluded that a coronavirus attacks two specific groups of cells in the lungs. One of these cells is called a goblet cell, and the other is called a ciliated cell. They explain that the goblet cells produce the mucus that forms a moisturizing layer on the respiratory canal, which is important to help maintain the moisture of the lungs, and thus maintain health. The ciliary cells are cells with hairs that point upward, and their function is to shovel any harmful substance suspended in mucus, such as bacteria, viruses, and dust particles, toward the throat to get rid of them. Coronavirus, on the other hand, infects these two groups of cells, which is observed with SARS, Professor Felder says. Felder added that the coronavirus infects these cells and begins to kill them, and its tissues begin to fall and collect in the lungs, and the lungs begin to become obstructed, which means that the patient has pneumonia. Then, the body's immune system is trying to respond because it realizes that the body is under attack, and this may lead to an overload of immunity, and then the immune system makes a major attack that damages healthy tissues in the lung, and this also may make breathing more difficult. The virus not only attacks the lungs but also the kidneys, which may lead to kidney failure and later death. The World Health Organization considered COVID-19 as a pandemic disease which means an epidemic that has spread over a large area that is prevalent through an entire county, continent, or the whole world.
This work aims to introduce a brief study of COVID-19, in addition to analysis the published papers in this field.

\section{MATERIALS AND METHODS}

This section including: COVID-19 mechanism, published papers on COVID-19, results, and analysis.

\subsection{COVID-19 Mechanism}

COVID-19 virus get in the human body via many ways: Eyes, nose, and mouth (Fig. 1):

- Via eyes: In this case, the virus has two main pathways that exit through tears or enter the lacrimal sac, then reach the nasal cavity and mouth, then go to the stomach and end with gastric juices or enter the respiratory system.

- Via nose: In this case, the virus is either expelled through the mucus or enters the respiratory system.

- Via mouth: In this case, the virus enters the stomach and kills them, or enters the respiratory system.

When the virus enters the respiratory system, it settles into the lung, where it begins to attack cells there. At that time, the immune system begins to attack the virus, and this leads to many accumulations in the lung that lead to a deficiency in the work of the lung. This means shortness of breath and sometimes leads to death.

\subsection{Published Papers on COVID-19}

COVID-19 key word is used is applied on Sciencedirect library at April 11, 2020 in which appeared 1741 published papers, all these papers are published in 2020. To determine this this work, 100 papers were focused onto be studied as shown in Fig. 2. To analyze these hundreds published papers, the first look at them was as follows: Eighty-nine $(89 \%)$ papers have been downloaded and the study has been done on it, eight $(8 \%)$ papers we could not download, two

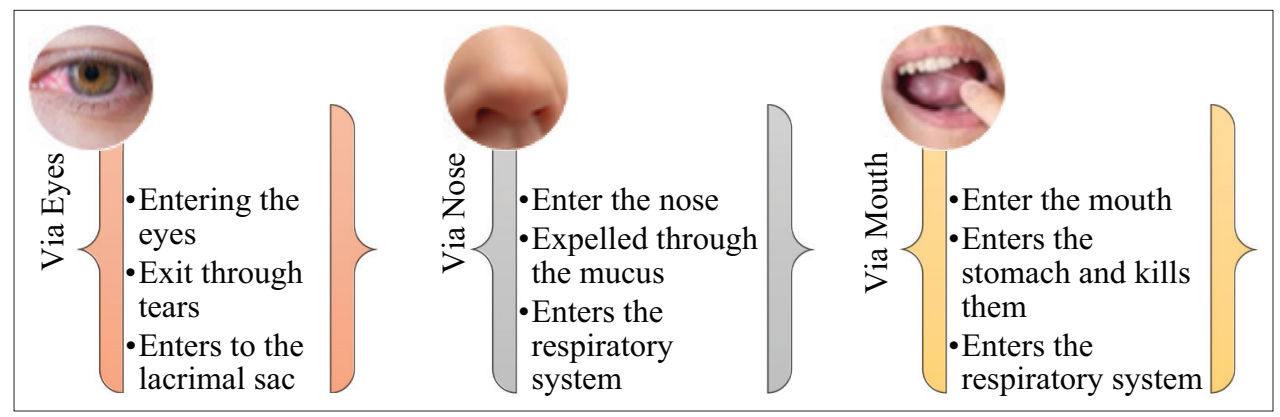

Fig. 1. Coronavirus disease-19 virus entering the human body. 
duplicated $(2 \%)$ papers, and finally one repeated (1\%) paper. In general, $11 \%$ of the papers are canceled and $89 \%$ of the papers are considered to be studied.

\section{RESULTS AND ANALYSIS}

Table 1 includes data on the published research papers that have been studied. This table was divided into several fields to clarify the quality of research and on any topic in which it was focused, these fields are paper ID, topic of the paper, applied method, and applied database, in addition to the country, in which the study was conducted and the country to which the researcher belongs.

Whatever was the area of interest, they are related to the medical part of COVID-19. The field of research area regarding to the score is divided into four main categories: Medicine 37 (42\%), statistics 19 (21\%), healthcare $17(19 \%)$, and management $16(18 \%)$. Medicine category including: Treatment $22(60 \%)$, diagnosis $6(16 \%)$, clinical $5(14 \%)$, emergency $1(2.5 \%)$, hepatic $1(2.5 \%)$, surgical $1(2.5 \%)$, and arrhythmia $1(2.5 \%)$. Statistical category including many fields in statistical analysis. Health-care category including: Health approach $5(30 \%)$, health workers $3(17 \%)$, personal health $3(17 \%)$, community pharmacies $2(12 \%)$, health-care provider $2(12 \%)$, global health $1(6 \%)$, and national care 1 (6\%). Management category including: Recommendation $6(38 \%)$, patient management $3(19 \%)$, control $2(13 \%)$, pharmaceutical care management $1(6 \%)$, internet hospital $1(6 \%)$, emergency $1(6 \%)$, clinical management $1(6 \%)$, and reorganization $1(6 \%)$.

The most important categories are related to the country in which the study was conducted and the country to which the researcher belongs. The country to which the researcher belongs is focusing on 25 countries and China settles on

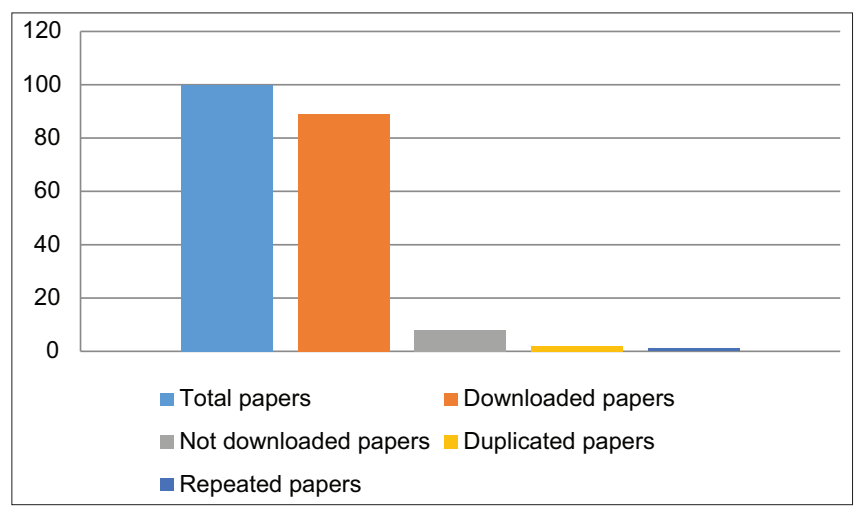

Fig. 2. Published papers on coronavirus disease-19. the top, as shown in Fig. 3. The score of the researchers by country related to COVID-19 is sorted top to bottom: China 37\%, USA $12 \%$, France $7 \%$, Taiwan $7 \%$, Canada $5 \%$, UK $5 \%$, Italy $5 \%$, India $4 \%$, and Spain $2 \%$, and the rest of countries are $1 \%$.

The country in which the study was conducted is focusing on 20 countries and also China settles on the top, as shown in Fig. 4. The score of the published research papers by country related to COVID-19 is sorted top to bottom: China 37\%, Global $27 \%$, USA $12 \%$, France $7 \%$, Taiwan 7\%, Canada $5 \%$, UK $5 \%$, Italy $5 \%$, India $4 \%$, and Spain $2 \%$, and the rest of countries are $1 \%$.

As a result of the previous research and studies obtained, it was found that the coronavirus has effected various places in the human body, and this virus has many different effects, including its effect on the lung and respiratory system. In general, its effect on heart murmurs, as well as on microvascular clots, in addition to other effects such high temperatures, intestinal disturbances, vomiting, and other disorders.

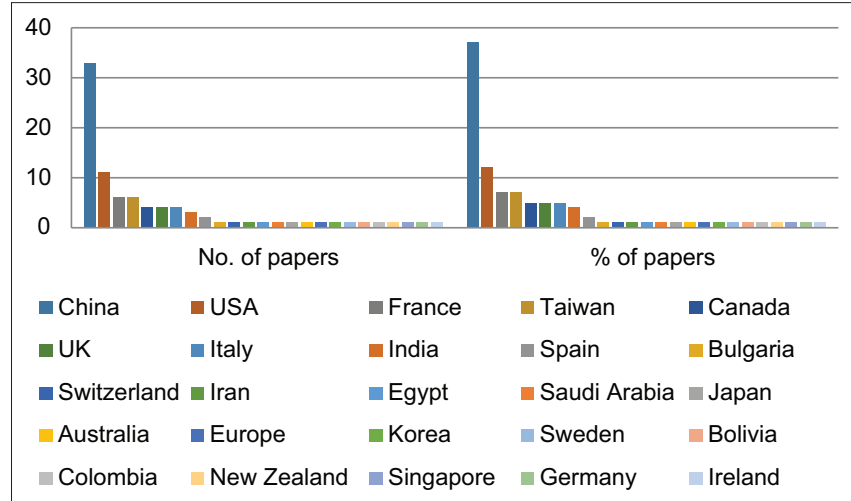

Fig. 3. Country to which the researcher belongs.

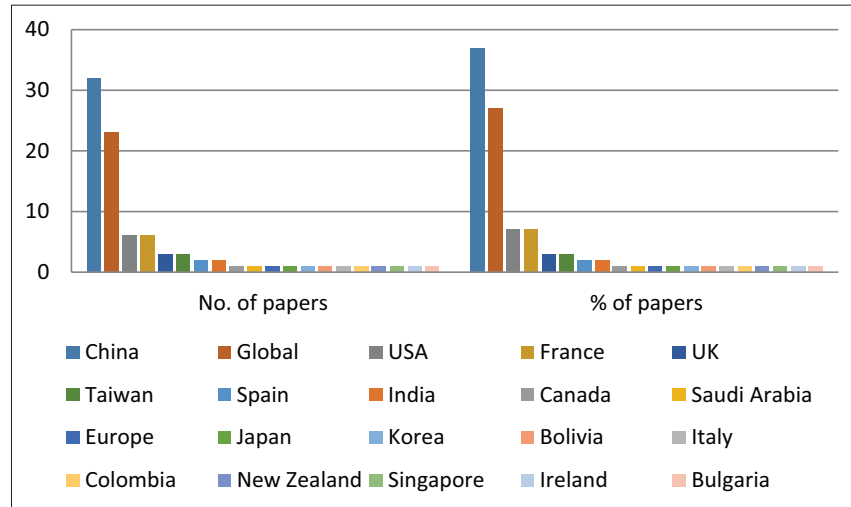

Fig. 4. Country in which the research was conducted. 
Muzhir Shaban Al-Ani and Dimah Mezher Shaban Al-Ani: Review Study Based on Covid-19

을

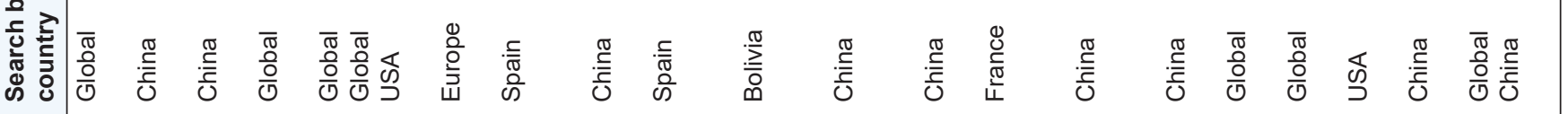

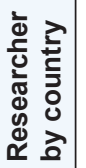

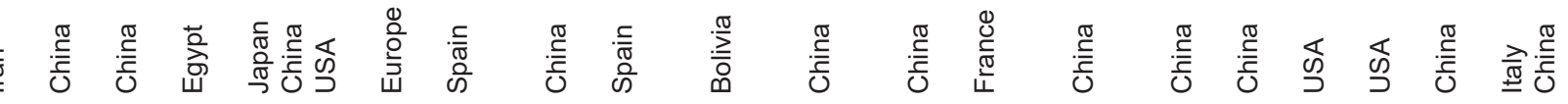

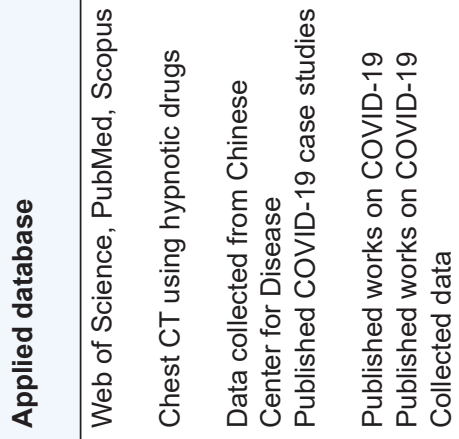

के व $\stackrel{\frac{0}{0}}{\frac{0}{\pi}}$

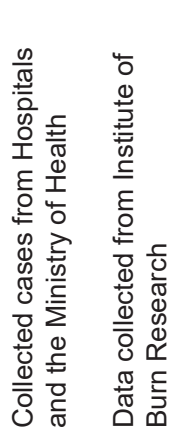

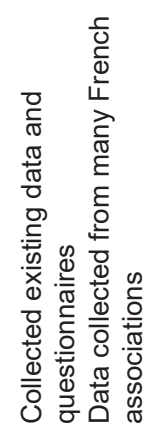

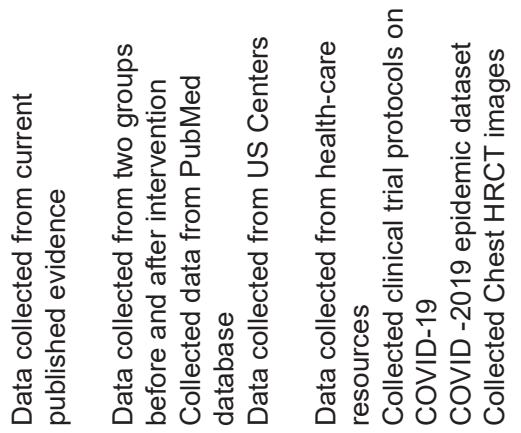

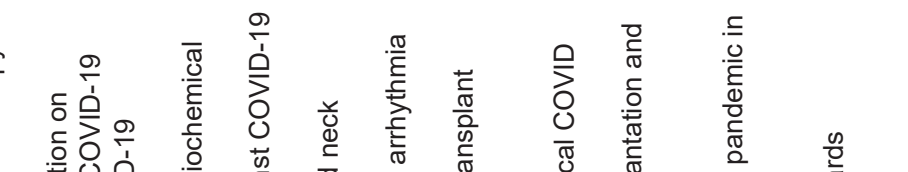

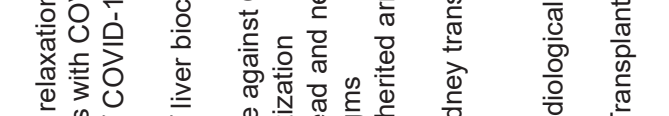

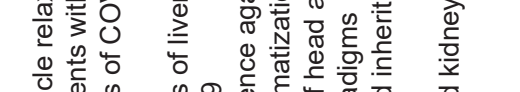

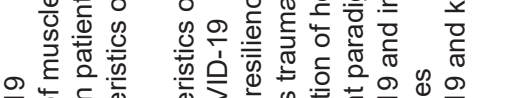

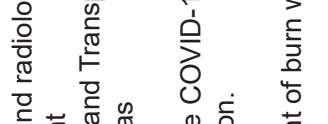

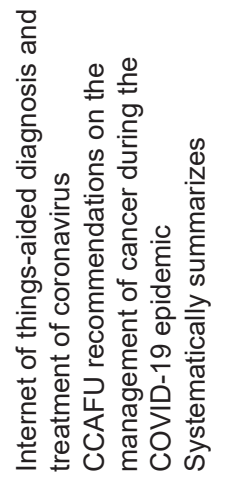
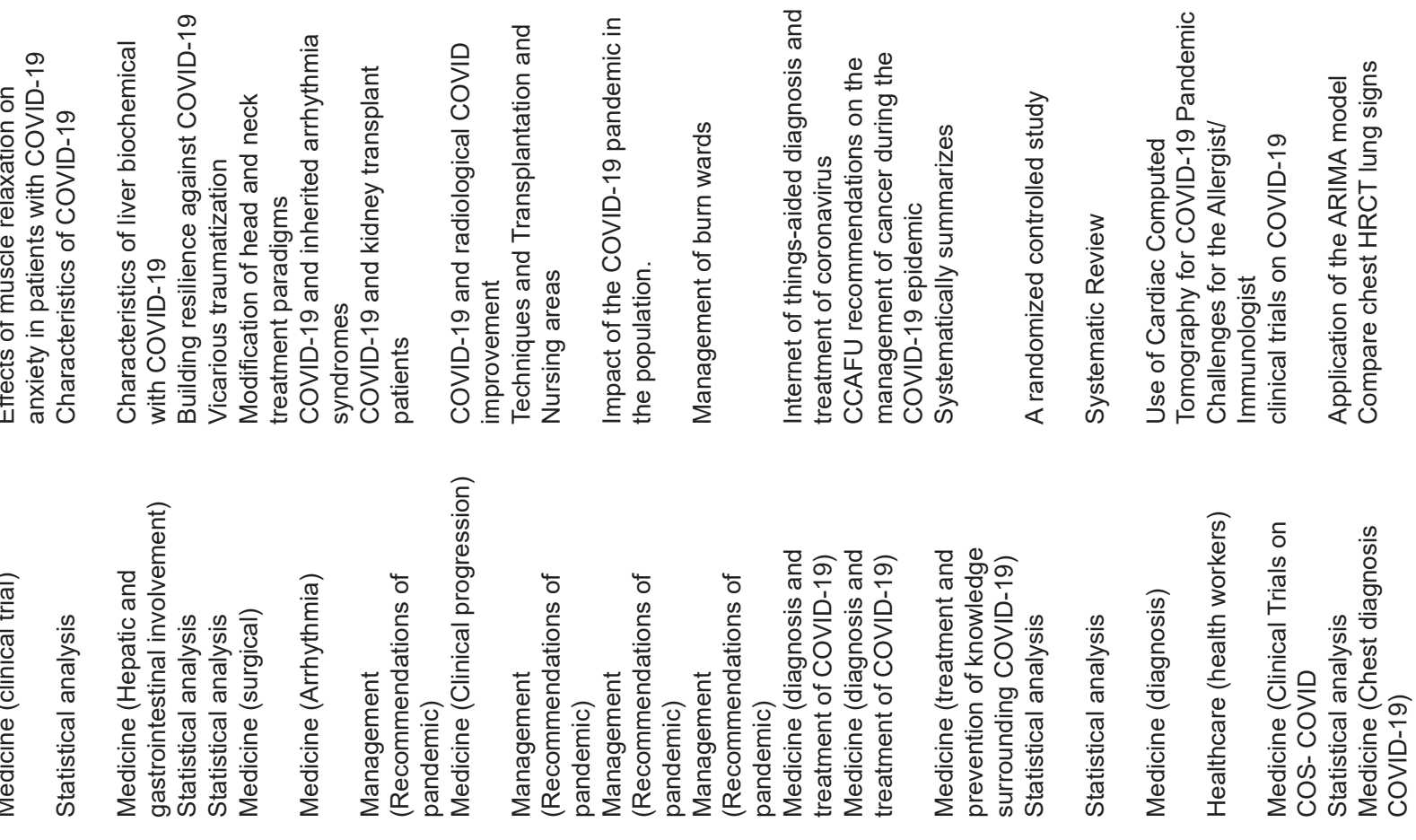
Muzhir Shaban Al-Ani and Dimah Mezher Shaban Al-Ani: Review Study Based on Covid-19

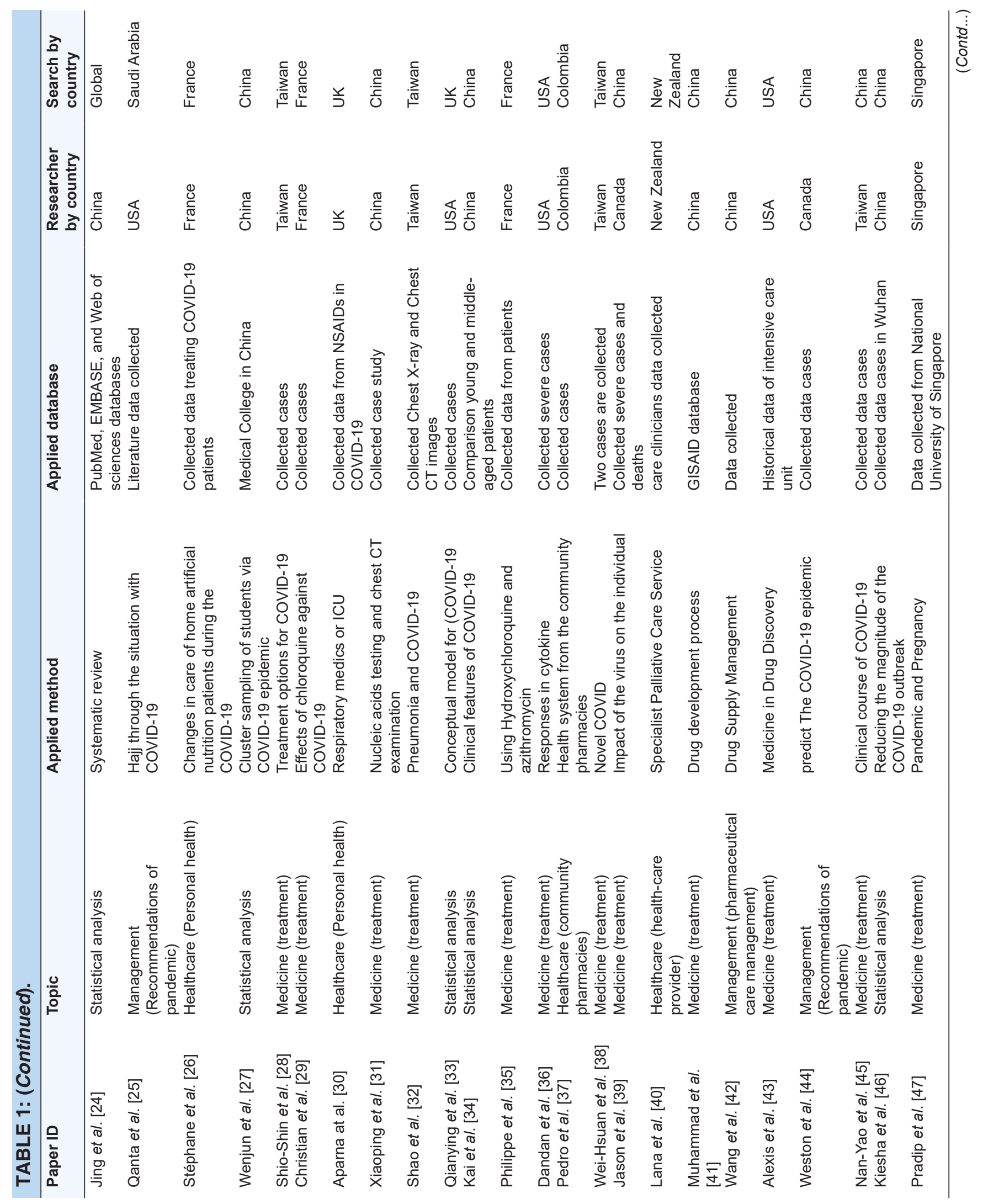


Muzhir Shaban Al-Ani and Dimah Mezher Shaban Al-Ani: Review Study Based on Covid-19

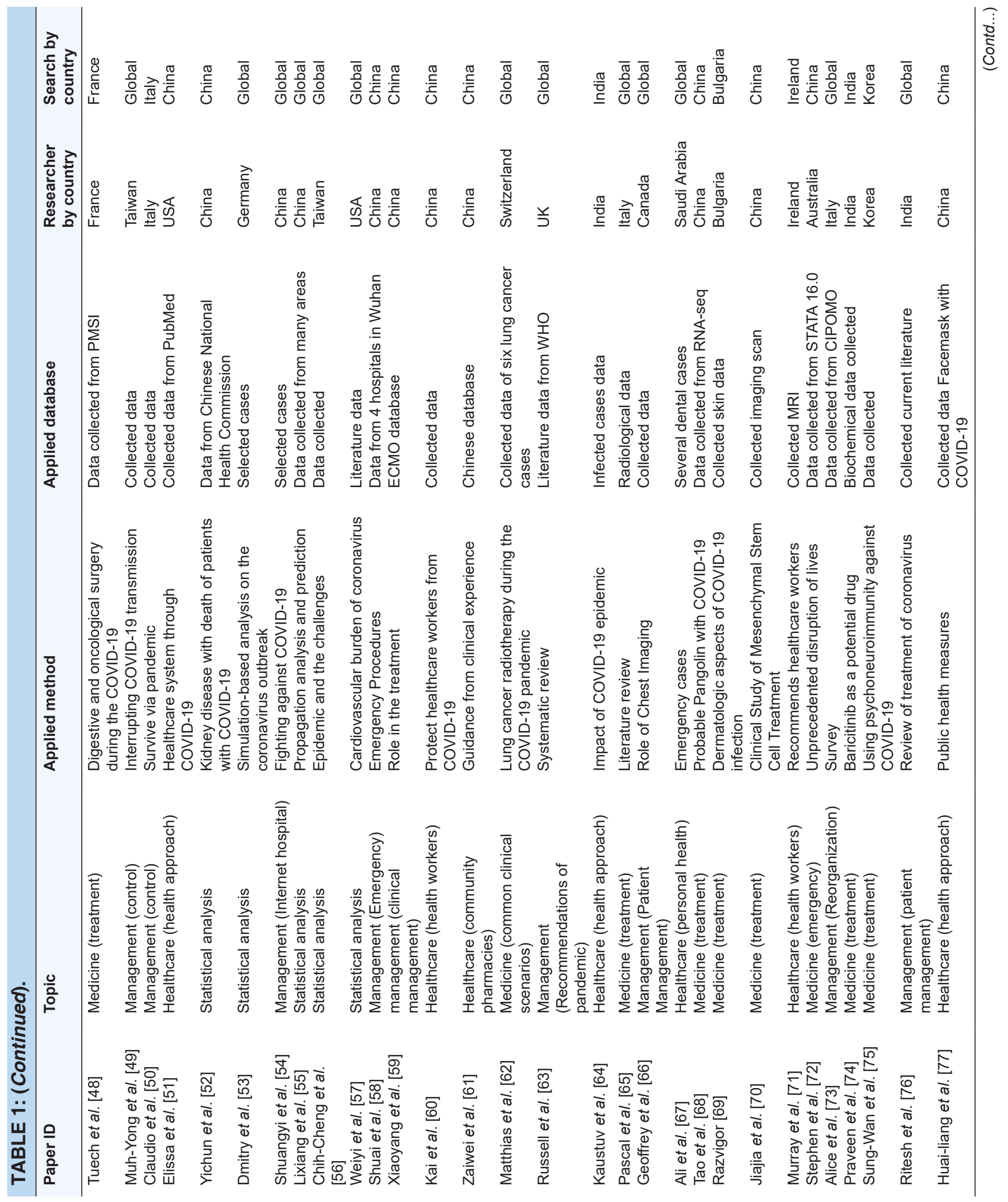




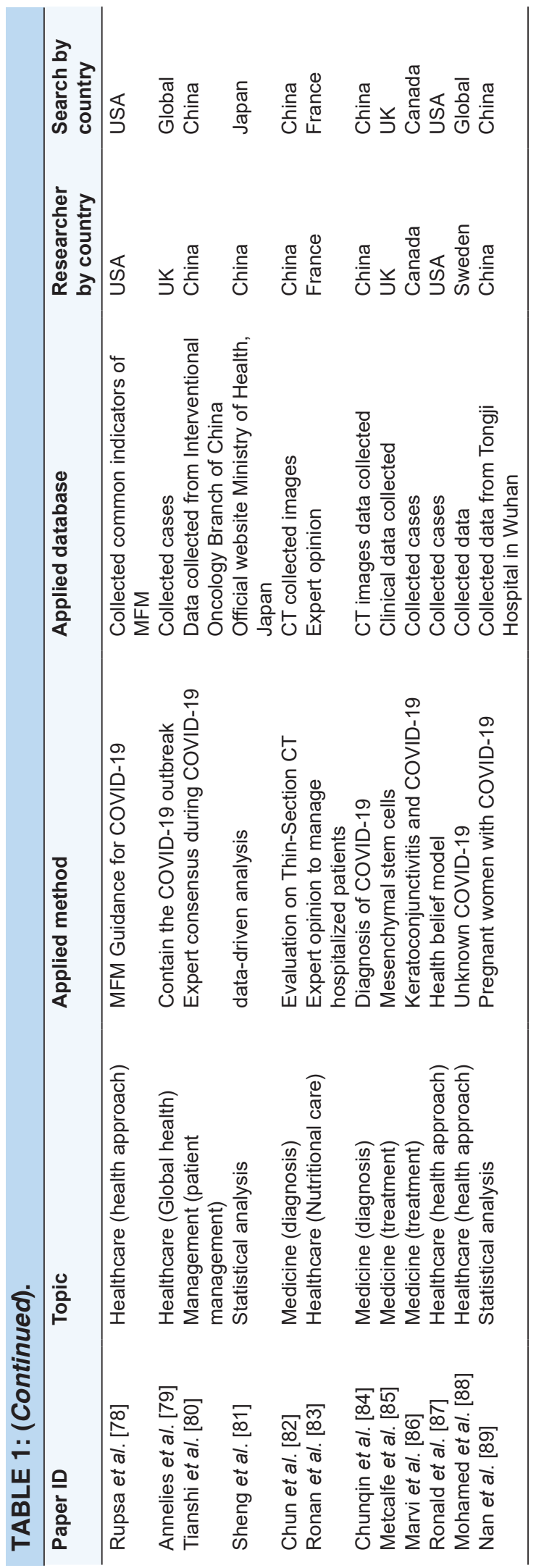

We know that coronavirus (COVID-19) started in China, so most of the research must begin and continue in this country to find a treatment for this disease. In spite of all the ongoing research papers on this subject, so far there is no effective treatment for this disease, on the other hand, all efforts are combined to achieve this goal and overcome this pandemic.

\section{CONCLUSIONS}

December 2019 was the start of an outbreak of coronavirus (COVID-19) in Wuhan, China. Then, at the beginning of the year 2020, this virus began to spread across the countries of the world gradually, as it appeared in all countries within only 2 months. During the spread of the coronavirus, researchers began working on this virus in different aspects and disciplines. This paper is based on a number of key factors that have been studied such as: Topic, applied method, applied database, researcher by country, and search by country. This search was applied on Sciencedirect library and conducted on April 11,2020. In this work, a focus was placed on a hundred research papers, including 899 downloaded and 11 research papers that we could not download, so this work is focused on research papers that were obtained only. As a conclusion of this work, a huge number of research papers are published in these 2 months and this research papers has been divided into four main categories: Medicine $42 \%$, statistics $21 \%$, healthcare $19 \%$, and management $18 \%$. Each of these categories also was divided into many sub-categories that related to narrow fields. Furthermore, it is clear that China settles on the top of the country in which the study was conducted and also on the top of the country to which the researcher belongs.

\section{ACKNOWLEDGMENT}

On this occasion, we would like to extend our sincere thanks and appreciation to the Sciencedirect database that contributed to supporting the research of COVID-19 by providing research papers without fees.

\section{REFERENCES}

[1] A. A. Jafari and S. Ghasemi. "The possible of immunotherapy for COVID-19: A systematic review". International Immunopharmacology, vol. 83, p. 106455, 2020.

[2] K. Liu, Y. Chen, D. Wu, R. Lin and L. Pan. "Effects of progressive muscle relaxation on anxiety and sleep quality in patients with COVID-19". Complementary Therapies in Clinical Practice, vol. 39, p. 101132, 2020.

[3] T. Xu, C. Chen, Z. Zhu, M. Cui and Y. Xue. "Clinical features and 
dynamics of viral load in imported and non-imported patients with COVID-19". International Journal of Infectious Diseases, vol. 94, pp. 68-71, 2020.

[4] S. Musa. "Hepatic and gastrointestinal involvement in coronavirus disease 2019 (COVID-19): What do we know till now"? Arab Journal of Gastroenterology, vol. 21, no. 1, pp. 3-8, 2020.

[5] R. Djalante, R. Shaw and A. DeWit. "Building resilience against biological hazards and pandemics: COVID-19 and its implications for the Sendai framework". Progress in Disaster Science, vol. 6, p. 100080, 2020.

[6] Z. Li, J. Ge, M. Yang, J. Feng and C. Yang. "Vicarious traumatization in the general public, members, and non-members of medical teams aiding in COVID-19 control". Brain, Behavior, and Immunity, vol. 88, pp. 916-919, 2020.

[7] A. T. Day, D. J. Sher, R. C. Lee, J. M. Truelson and E. A. Gordin. "Head and neck oncology during the COVID-19 pandemic: Reconsidering traditional treatment paradigms in light of new surgical and other multilevel risks". Oral Oncology, vol. 105, p. 104684, 2020.

[8] C. I. Wu, P. G. Postema, E. Arbelo, E. R. Behr and A. A. M. Wilde. "SARS-CoV-2, COVID-19 and inherited arrhythmia syndromes". Heart Rhythm, vol. 2020, p. 24, 2020.

[9] V. López, T. Vázquez, J. Alonso-Titos, M. "Cabello and Grupo de Estudio GREAT. "Recommendations on management of the SARSCoV-2 coronavirus pandemic (Covid-19) in kidney transplant patients". Nefrología, vol. 40, no. 3, pp. 265-271, 2020.

[10] J. Chen, T. Qi, L. Liu, Y. Ling and H. Lu. "Clinical progression of patients with COVID-19 in Shanghai, China". Journal of Infection, vol. 80, no. 5, pp. e1-e6, 2020.

[11] R. C. Pérez, S. Álvarez, L. Llanos, A. N. Ares and D, Díaz-Pérez. "Recomendaciones de consenso separ y aeer sobre el uso de la broncoscopia y la toma de muestras de la via respiratoria en pacientes con sospecha o con infeccion confirmada por Covid-19". Archivos de Bronconeumología, vol. 56, no. 2, pp. 19-26, 2020.

[12] J. P. Escalera-Antezana, N. F. Lizon-Ferrufino, A. MaldonadoAlanoca, G. Alarcón-De-la-Vega and LANCOVID. "Clinical features of cases and a cluster of coronavirus disease 2019 (COVID-19) in Bolivia imported from Italy and Spain". Travel Medicine and Infectious Disease, vol. 35, p. 101653, 2020.

[13] S. Ma, Z. Yuan, Y. Peng, J. Chen and G. Luo. "Experience and suggestion of medical practices for burns during the outbreak of COVID-19". Burns, vol. 46, no. 4, pp. 749-755, 2020.

[14] L. Bai, D. Yang, X. Wang, L. Tong and F. Tan. "Chinese experts' consensus on the Internet of Things-aided diagnosis and treatment of coronavirus disease 2019 (COVID-19)". Clinical eHealth, vol. 3, pp. 7-15, 2020.

[15] A. Mejean, M. Rouprêt, F. Rozet, K. Bensalah and Le Comité de Cancérologie de l'Association Française d'Urologie. "Recommandations CCAFU sur la prise en charge des cancers de l'appareil urogénital en période d'épidémie au Coronavirus COVID-19". Progrès en Urologie, vol. 30, no. 5, pp. 221-231, 2020.

[16] L. S. Wang, Y. R. Wang, D. W. Ye and Q. Q. Liu. "A review of the 2019 novel coronavirus (COVID-19) based on current evidence". International Journal of Antimicrobial Agents, vol. 55, no. 6, p. 105948, 2020.

[17] K. Liu, W. Zhang, Y. Yang, J. Zhang and Y. Chen. "Respiratory rehabilitation in elderly patients with COVID-19: A randomized controlled study". Complementary Therapies, vol. 39, p. 101166, 2020.

[18] C. Bao, X. Liu, H. Zhang, Y. Li and J. Liu. "COVID-19 computed tomography findings: A systematic review and meta-analysis". Journal of the American College of Radiology, vol. 17, pp. 701-709, 2020.

[19] A. D. Choi, S. Abbara, K. R. Branch, G. M. Feuchtner and R. Blankstein. "Society of cardiovascular computed tomography guidance for use of cardiac computed tomography amidst the COVID-19 pandemic". Journal of Cardiovascular Computed Tomography, vol. 14, no. 1, pp. 101-104, 2020.

[20] P. Bansal, T. A. Bingemann, M. Greenhawt, G. Mosnaim and M. Shaker. Clinician wellness during the COVID-19 pandemic: Extraordinary times and unusual challenges for the allergist/ immunologist. The Journal of Allergy and Clinical Immunology, vol. 8, no. 6, pp. 1781-1790, 2020.

[21] X. Jin, B. Pang, J. Zhang, Q. Liu and B. Zhang. "Core outcome set for clinical trials on coronavirus disease 2019 (COS-COVID)". Engineering, vol. 1, pp. 2-6, 2020.

[22] D. Benvenuto, M. Giovanetti, L. Vassallo, S. Angeletti and M. Ciccozzi. "Application of the ARIMA model on the COVID-2019 epidemic dataset". Data in Brief, vol. 29, p. 105340, 2020.

[23] Z. Chen, H. Fan, J. Cai, Y. Li and J. Sun. "High-resolution computed tomography manifestations of COVID-19 infections in patients of different ages". European Journal of Radiology, vol. 126, p. 108972, 2020.

[24] J. Yang, Y. Zheng, X. Gou, K. Pu and Y. Zhou. "Prevalence of comorbidities in the novel Wuhan coronavirus (COVID-19) infection: A systematic review and meta-analysis". International Journal of Infectious Diseases, vol. 94, pp. 91-95, 2020.

[25] Q. A. Ahmed and Z. A. Memish. "The cancellation of mass gatherings (MGs)? Decision making in the time of COVID-19". Travel Medicine and Infectious Disease, vol. 34, p. 101631, 2020.

[26] S. M. Schneider, V. Albert, N. Barbier, D. Barnoud and P. Déchelotte. "Adaptations de la prise en charge des patients en nutrition artificielle a domicile au cours de l'épidémie virale COVID-19 en France: Avis du comite de nutrition a domicile de la societe francophone de nutrition clinique et metabolisme (SFNCM)". Nutrition Clinique et Métabolisme, vol. 34, no. 2, pp. 105-107, 2020.

[27] W. Cao, Z. Fang, G. Hou, M. Han and J. Zheng. "The psychological impact of the COVID-19 epidemic on college students in China". Psychiatry Research, vol. 287, p. 112934, 2020.

[28] S. S. Jean, P. I. Lee and P. R. Hsueh. "Treatment options for COVID-19: The reality and challenges". Journal of Microbiology, Immunology and Infection, vol. 53, no, 3, pp. 436-443, 2020.

[29] C. A. Devaux, J. M. Rolain, P. Colson and D. Raoult. "New insights on the antiviral effects of chloroquine against coronavirus: What to expect for COVID-19"? International Journal of Antimicrobial Agents, vol. 55, no. 5, p. 105938, 2020.

[30] A. Viswanath and P. Monga. "Working through the COVID-19 outbreak: Rapid review and recommendations for MSK and allied heath personnel". Journal of Clinical Orthopaedics and Trauma, vol. 11, no. 3, pp. 500-503, 2020.

[31] X. Yin, L. Dong, Y. Zhang, W. Bian and H. Li. "A mild type of childhood Covid-19 a case report". Radiology of Infectious Diseases, in press, 2020.

[32] S. C. Cheng, Y. C. Chang, Y. L. Fan Chiang, Y. C. Chien and Y. N. Hsu. "First case of coronavirus disease 2019 (COVID-19) pneumonia in Taiwan". Journal of the Formosan Medical Association, vol. 119, no. 3, pp. 747-751, 2020.

[33] Q. Lin, S. Zhao, D. Gao, Y. Lou and D. He. "A conceptual model for the coronavirus disease 2019 (COVID-19) outbreak in 
Wuhan, China with individual reaction and governmental action". International Journal of Infectious Diseases, vol. 93, pp. 211-216, 2020.

[34] K. Liu, Y. Chen, R. Lin and K. Han. "Clinical features of COVID-19 in elderly patients: A comparison with young and middle-aged patients". Journal of Infection, vol. 80, no. 6, pp. e14-e18, 2020.

[35] P. Gautret, J. C. Lagier, P. Parola, V. T. Hoang and D. Raoult. "Hydroxychloroquine and azithromycin as a treatment of COVID-19: Results of an open-label non-randomized clinical trial". International Journal of Antimicrobial Agents, vol. 56, no. 1. p. 105949, 2020.

[36] D. Wu and X. O. Yang. "TH17 responses in cytokine storm of COVID-19: An emerging target of JAK2 inhibitor Fedratinib". Journal of Microbiology, Immunology and Infection, vol. 53, no. 3. pp. 368-370, 2020.

[37] P. Amariles, M. Ledezma-Morales, A. Salazar-Ospina and J. A. Hincapié-García. "How to link patients with suspicious COVID-19 to health system from the community pharmacies? A route proposal". Research in Social and Administrative Pharmacy, vol. 23, pp. 30248-30249, 2020.

[38] W. H. Huang, L. C. Teng, T. K. Yeh, Y. J. Chen and P. Y. Liu. "2019 novel coronavirus disease (COVID-19) in Taiwan: Reports of two cases from Wuhan, China". Journal of Microbiology, Immunology and Infection, vol. 53, no. 3, pp. 481-484, 2020.

[39] J. A. Tetro. "Is COVID-19 receiving ADE from other corona viruses"? Microbes and Infection, vol. 22, pp. 72-73, 2020.

[40] L. Ferguson and D. Barham. "Palliative care pandemic pack: A specialist palliative care service response to planning the COVID-19 pandemic". Journal of Pain and Symptom Management, vol. 60, no. 1, pp. e18-e20, 2020.

[41] M. T. ul Qamar, S. M. Alqahtani, M. A. Alamri and L. L. Chen. "Structural basis of SARS-CoV-2 3CLpro and anti-COVID-19 drug discovery from medicinal plants". Journal of Pharmaceutical Analysis, vol. 1, pp. 1-9, 2020.

[42] W. Ying, Y. Qian and Z. Kun. "Drugs supply and pharmaceutical care management practices at a designated hospital during the COVID-19 epidemic". Research in Social and Administrative Pharmacy, vol. 1, pp. 1-4, 2020.

[43] A. Nahama, R. Ramachandran, A. F. Cisternas and H. Ji. "The role of afferent pulmonary innervation in poor prognosis of acute respiratory distress syndrome in COVID-19 patients and proposed use of resiniferatoxin (RTX) to improve patient outcomes in advanced disease state: A review". Medicine in Drug Discovery, vol. 5, p. 100033, 2020.

[44] W. C. Roda, M. B. Varughese, D. Han and M. Y. Li. "Why is it difficult to accurately predict the COVID-19 epidemic"? Infectious Disease Modelling, vol. 52020, pp. 271-281, 2020.

[45] N. Y. Lee, C. W. Li, H. P. Tsai, P. L. Chen and W. C. Ko. "A case of COVID-19 and pneumonia returning from Macau in Taiwan: Clinical course and anti-SARS-CoV-2 IgG dynamic". Journal of Microbiology, Immunology and Infection, vol. 53, no. 3, pp. 485487, 2020.

[46] K. Prem, Y. Liu, T. W. Russell, A. J. Kucharski and P. Klepac. "The effect of control strategies to reduce social mixing on outcomes of the COVID-19 epidemic in Wuhan, China: A modelling study". The Lancet, vol. 1, pp. 1-6, 2020.

[47] P. Dashraath, W. J. L. Jeslyn, L. M. X. Karen, L. L. Min and S. L. Lin. "Coronavirus disease 2019 (COVID-19) pandemic and pregnancy". American Journal of Obstetrics and Gynecology, vol. 222, no. 6, pp. 521-531, 2020.
[48] J. J. Tuech, A. Gangloff, F. Di Fiore, P. Michel and L. Schwarz. "Strategy for the practice of digestive and oncological surgery during the Covid-19 epidemic". Journal of Visceral Surgery, vol. 157, pp. S7-S12, 2020.

[49] M. Y. Yen, J. Schwartz, S. Y. Chen, C. C. King and P. R. Hsueh. "Interrupting COVID-19 transmission by implementing enhanced traffic control bundling: Implications for global prevention and control efforts". Journal of Microbiology, Immunology and Infection, vol. 53, no. 3, pp. 377-380, 2020.

[50] C. Guerci, A. Maffioli, A. A. Bondurri, L. Ferrario and P. Danelli. "Covid-19: How can a department of general surgery survive to a pandemic? Surgery, vol. 167, no. 6, pp. 909-911, 2020.

[51] E. Driggin, M. V. Madhavan, B. Bikdeli, T. Chuich and S. A. Parikh. "Cardiovascular considerations for patients, health care workers, and health systems during the coronavirus disease 2019 (COVID-19) pandemic". Journal of the American College of Cardiology, vol. 75, no. 18, pp. 2352-2371, 2020.

[52] Y. Cheng, R. Luo, K. Wang, M. Zhang and G. Xu. "Kidney disease is associated with in-hospital death of patients with COVID-19". Kidney International, vol. 97, no. 5, pp. 829-838, 2020.

[53] D. Ivanov. "Predicting the impacts of epidemic outbreaks on global supply chains: A simulation-based analysis on the coronavirus outbreak (COVID-19/SARS-CoV-2) case". Transportation Research Part E: Logistics and Transportation Review, vol. 136, p. 101922, 2020.

[54] S. Sun, K. Yu, Z. Xie and X. Pan. "China empowers Internet hospital to fight against COVID-19". Journal of Infection, vol. 81, no. 1, pp. e67-e68, 2020.

[55] L. Li, Z. Yang, Z. Dang, C. Meng and Y. Shao. "Propagation analysis and prediction of the COVID-19". Infectious Disease Modelling, vol. 52020, pp. 282-292, 2020.

[56] C. C. Lai, T. P. Shih, W. C. Ko, H. J. Tang and P. R. Hsueh. "Severe acute respiratory syndrome coronavirus 2 (SARS-CoV-2) and coronavirus disease-2019 (COVID-19): The epidemic and the challenges". International Journal of Antimicrobial Agents, vol. 55, no. 3, 105924, 2020.

[57] W. Tan and J. Aboulhosn. "The cardiovascular burden of coronavirus disease 2019 (COVID-19) with a focus on congenital heart disease". International Journal of Cardiology, vol. 309, pp. 70-77, 2020.

[58] S. Zhao, K. Ling, H. Yan, L. Zhong and X. Chen. "Anesthetic management of patients with COVID 19 infections during emergency procedures". Journal of Cardiothoracic and Vascular Anesthesia, vol. 34, no. 5, pp. 1125-1131, 2020.

[59] X. Hong, J. Xiong, Z. Feng and Y. Shi. "Extracorporeal membrane oxygenation (ECMO): Does it have a role in the treatment of severe COVID-19"? International Journal of Infectious Diseases, vol. 94, pp. 78-80, 2020.

[60] K. Xu, X. Lai and L. Zheng. "Suggestions on the prevention of COVID-19 for health care workers in department of otorhinolaryngology head and neck surgery". World Journal of Otorhinolaryngology Head and Neck Surgery, vol. 1, pp. 1-3, 2020.

[61] Z. Song, Y. Hu, S. Zheng, L. Yang and R. Zhao. "Hospital pharmacists' pharmaceutical care for hospitalized patients with COVID-19: Recommendations and guidance from clinical experience". Research in Social and Administrative Pharmacy, vol. 1, pp. 1-27, 2020.

[62] M. Guckenberger, C. Belka, A. Bezjak, J. Bradley and D. Palma. "Practice recommendations for lung cancer radiotherapy during the COVID-19 pandemic: An ESTRO-ASTRO consensus statement". 
Radiotherapy and Oncology, vol. 146, pp. 223-229, 2020.

[63] R. M. Viner, S. J. Russell, H. Croker, J. Packer and R. Booy. "School closure and management practices during coronavirus outbreaks including COVID-19: A rapid systematic review". The Lancet Child and Adolescent Health, vol. 1, pp. 1-16, 2020.

[64] K. Chatterjee, K. Chatterjee, A. Kumar and S. Shankar. "Healthcare impact of COVID-19 epidemic in India: A stochastic mathematical model". Medical Journal Armed Forces India, vol. 76, pp. 147-155, 2020.

[65] P. Lomoro, F. Verde, F. Zerboni, I. Simonetti and A. Martegani. "COVID-19 pneumonia manifestations at the admission on chest ultrasound, radiographs, and CT: single-center study and comprehensive radiologic literature review". European Journal of Radiology Open, vol. 7, p. 100231, 2020.

[66] G. D. Rubin, C. J. Ryerson, L. B. Haramati, N. Sverzellati and A. N. Leung. "The Role of chest imaging in patient management during the COVID-19 pandemic: A multinational consensus statement from the fleischner society". Chest, vol. 158, pp. 106-116, 2020.

[67] A. Alharbi, S. Alharbi and S. Alqaidi. "Guidelines for dental care provision during the COVID-19 pandemic". The Saudi Dental Journal, vol. 32, pp. 181-186, 2020.

[68] T. Zhang, Q. Wu and Z. Zhang. "Probable pangolin origin of SARSCoV-2 associated with the COVID-19 outbreak". Current Biology, vol. 30 , no. 76, pp. 1346-1351, 2020.

[69] R. Darlenski and N. Tsankov. "Covid-19 pandemic and the skin what should dermatologists know"? Clinics in Dermatology, in press, 2020.

[70] J. Chen, C. Hu, L. Chen, L. Tang and L. Li. "Clinical study of mesenchymal stem cell treatment for acute respiratory distress syndrome induced by epidemic influenza a (H7N9) infection: A hint for COVID-19 treatment". Engineering, vol. 1, pp. 1-6, 2020.

[71] O. M. Murray, J. M. Bisset, P. J. Gilligan, M. M. Hannan and J. G. Murray. "Respirators and surgical facemasks for COVID-19: Implications for MRI". Clinical Radiology, vol. 75, no. 6, pp. 405407,2020

[72] S. X. Zhang, Y. Wang, A. Rauch and F. Wei. "Unprecedented disruption of lives and work: Health, distress and life satisfaction of working adults in China one month into the COVID-19 outbreak". Psychiatry Research, vol. 288, p. 112958, 2020.

[73] A. Indini, C. Aschele, D. Bruno, L. Cavanna and F. Grossi. "Reorganization of medical oncology departments during COVID-19 pandemic: A nationwide Italian survey". European Journal of Cancer, vol. 132, pp. 17-32, 2020.

[74] D. Praveen, P. R. Chowdary and M. V. Aanandhi. "Baricitinib a januase kinase inhibitor not an ideal option for management of covid 19. International Journal of Antimicrobial Agents, vol. 55, no, 5, p. 105967, 2020.

[75] S. W. Kim and K. P. Su. "Using psychoneuroimmunity against COVID-19". Brain, Behavior, and Immunity, vol. 87, pp. 4-5, 2020.

[76] R. Gupta and A. Misra. "Contentious issues and evolving concepts in the clinical presentation and management of patients with COVID-19 infection with reference to use of therapeutic and other drugs used in Co-morbid diseases (hypertension, diabetes etc)". Diabetes and Metabolic Syndrome, vol. 14, no. 3, pp. 251-254.
[77] H. L. Wu, J. Huang, C. J. P. Zhang, Z. He and W. K. Ming. "Facemask shortage and the novel coronavirus disease (COVID-19) outbreak: Reflections on public health measures". EClinicalMedicine, vol. 21, p. 100329, 2020.

[78] R. C. Boelig, G. Saccone, F. Bellussi and V. Berghella. "MFM guidance for COVID-19". American Journal of Obstetrics and Gynecology, vol. 2, no. 2, p. 100106, 2020.

[79] A. Wilder-Smith, C. J. Chiew and V. J. Lee. "Can we contain the COVID-19 outbreak with the same measures as for SARS"? The Lancet Infectious Diseases, vol. 1, pp. 1-10, 2020.

[80] T. Lyu, L. Song, L. Jin, Y. Zou and Interventional Oncology Branch of China Anti-Cancer Association. "Expert consensus on the procedure of interventional diagnosis and treatment of cancer patients during the COVID-19 epidemic". Journal of Interventional Medicine, vol. 3, no. 2, pp. 61-64, 2020.

[81] S. Zhang, M. Diao, W. Yu, L. Pei and D. Chen. "Estimation of the reproductive number of novel coronavirus (COVID-19) and the probable outbreak size on the Diamond Princess cruise ship: A data-driven analysis". International Journal of Infectious Diseases, vol. 93, pp. 201-204, 2020.

[82] C. S. Guan, Z. B. Lv, S. Yan, Y. N. Du and B. D. Chen. "Imaging features of coronavirus disease 2019 (COVID-19): Evaluation on thin-section CT". Academic Radiology, vol. 27, no. 5, pp. 609-613, 2020.

[83] R. Thibault, D. Quilliot, P. Seguin, F. Tamion and P. Déchelotte. "Stratégie de prise en charge nutritionnelle à l'hôpital au cours de l'épidémie virale Covid-19: Avis d'experts de la societe francophone de nutrition clinique et metabolisme (SFNCM)". Nutrition Clinique et Métabolisme, vol. 34, no. 2, pp. 97-104, 2020.

[84] C. Long, H. Xu, Q. Shen, X. Zhang and H. Li. "Diagnosis of the coronavirus disease (COVID-19): rRT-PCR or CT"? European Journal of Radiology, vol. 126, p. 108961, 2020.

[85] S. M. Metcalfe. "Mesenchymal stem cells and management of COVID-19 pneumonia". Medicine in Drug Discovery, vol. 5, p. 100019, 2020.

[86] M. Cheema, H. Aghazadeh, S. Nazarali, A. Ting and C. Solarte. "Keratoconjunctivitis as the initial medical presentation of the novel coronavirus disease 2019 (COVID-19): A case report". Canadian Journal of Ophthalmology, vol. 1, pp. 1-7, 2020.

[87] R. R. Carico, J. Sheppard and C. B. Thomas. "Community pharmacists and communication in the time of COVID-19: Applying the health belief model". Research in Social and Administrative Pharmacy, vol. 1, pp. 1-11, 2020.

[88] N. Yu, W. Li, Q. Kang, Z. Xiong, W. M. E. El Zowalaty and J. D. Järhult. "From SARS to COVID-19: A previously unknown SARS related coronavirus (SARS-CoV-2) of pandemic potential infecting humans call for a one health approach". One Health, vol. 9, p. 100124, 2020.

[89] N. Yu, W. Li, Q. Kang, Z. Xiong, S. Wang, X. Lin, Y. Liu, J. Xiao, H. Liu, D. Deng, S. Chen, W. Zeng, L. Feng and J. Wu. "Clinical features and obstetric and neonatal outcomes of pregnant patients with COVID-19 in Wuhan, China: A retrospective, single-center, descriptive study". The Lancet Infectious Diseases, vol. 1, pp. 1-6, 2020. 